\title{
MENINGKATKAN KINERJA DAN MENGELOLA TIM SECARA EFEKTIF
}

\author{
Oleh:
}

\section{Abstrak}

Didi Wahyu Sudirman

FIS UNY

Orang bergabung dengan kelompok karena kebutuhan mereka akan rasa aman, status, harga diri, afiliasi, kekuasaan dan atau prestasi. Dalam hal ini banyak organisasi menggunakan tim untuk melaksanakan tugas-tugas organisasi dan memecahkan masalah.

Tim kerja adalah kelompok formal yang terdiri dari individuindividu terpisah dan bertanggung jawab atas tercapainya suatu sasaran. Dengan demikian semua tim kerja adalah kelompok, tetapi hanya kelompok-kelompok formal yang menjadi tim kerja.

Untuk mengembangkan tim agar efektif maka setiap orang dalam tim harus mengetahui dan memahami dengan jeleris tujuan dan harapannya, peran khusus apa yang harus mereka lakukan, sekaligus memberi kesempatan para anggota tim mencurahkan ide-ide untuk mencapai sasaran, bertanggungjawab atas hasil tim tersebut. Dalam hal mengelola tim agar lebih efektif dapat digunakan pendekatan keempat fungsi dasar manjemen ; perencanaan, pengorganisasian, pemimpinan dan pengendalian.
\end{abstract}

Kata kunci : organisasi, pengelolaan tim

\section{Pendahuluan}

Meskipun organisasi-organisasi dikelola dengan baik, belum tentu selalu bekerja secara efisien dan efektif. Banyak masalah-masalah yang dihadapi organisasi berkait dengan masalah-masalah sumber daya organisasi tersebut. Oleh karena itu pihak manajemen harus mampu mengidentifikasi masalah-masalah yang bisa menghambat kinerja organisasi.
Salah satu ciri yang membedakan sebuah organisasi adalah kemampuannya untuk mengetahui kapan persoalan-persoalan harus ditangani dan kemudian segera melakukan sesuatu tentang hal itu.

"Ada satu keadaan hakiki bahwa pihak manajemen tidak bisa berdiri sendiri untuk menyelesaikan berbagai masalah proses kerja dari sudut pandang menyeluruh atau me- 
nanganinya secara parsial. Alasannya bahwa tidak ada satu orangpun yang akan memiliki gagasan-gagasan paling baik, akan tetapi gagasan-gagasan terbaik akan 'muncul dari kecerdasan bersama yang ada dalam tim. Anggota tim dalam realita saling melakukan curah gagasan yang mampu menghasilkan suatu proses kreatifitas tim yang solid. (Didi Wahyu Sudirman, 2002:8)

Organisasi saat ini pada umumnya mengoptimalkan kerja tim dan restrukturisasi pekerjaan dilakukan disekitar kelompok-kelompok dan bukannya individu. Hal ini dilakukan karena m:snajemen mulai menyadari pentingnya peran tim yang efektif. Oleh sebab itu pengembangan dan pemahaman perilaku tentang kelompok perlu mendapat perhatian pihak mànajemen. Dengan pemahaman kelompok, manajemen akan mengetahui sejauh mana perilaku kelompok tersebut.

Sebuah kelompok bukan merupakan kuantitas atau penjumlahan perilaku masing-masing individu dalam kelompok tersebut. Karena individu bertindak saling berlainan dalam kelompok dibandingkan pada saat mereka sendirian. Jadi apabila ingin memahami perilaku organisasi secara tuntas, maka perlu mengkaji kelompok yang ada dalam organisasi tersebut. Sebagai contoh dalam organisasi dikenal kelompok formal meliputi kelompok komando, tim fungsional-silang, tim pengelola diri sendiri dan satuan tugas. Dibalik itu dikenal juga kelompok informal yang sifatnya sosial. Kelompok ini terbentuk secara alamiah di lingkungan kerja yang muncul karena adanya kebutuhan hubungan sosial. Kelompok informal cenderung terbentuk disekitar persahabatan dan kepentingan bersama.

Pihak manajemen juga hendaknya memahami bahwa adanya kelompok dalam organisasi karena adanya unsur pencapaian tujuan, kekuasaan, afiliasi, harga diri, status, dan rasa aman. Walaupun disadari bahwa dalam kinerja kelompok tidak lepas dengan kemungkinan timbulnya konflik yang dalam proses bisa menurunkan kinerja kelompok. Di sifilah peran manajemen mengubah kelompok menjadi tim yang efektif.

\section{Efektifitas Kelompok Sebagai Tim}

Apabila dicermati banyak organisasi menggunakan tim formal untuk menjalankan kegiatan kerja. Bahkan organisasi yang kecilpun menggunakan tim untuk melakukan tugas-tugas organisasi dan memecahkan masalah. Tim banyak difungsikan unituk menyelesaikan tugas-tugas organisasi.

Berbicara mengenai pengertian tim, pada umumnya istilah tim sudah banyak dikenal dan dimengerti. Meskipun demikian istilah tim yang dimaksud adalah : kelompok formal yang terdiri dari individu-individu teroisah, dan bertanggungja- 
wab atas tercapainya satu sasaran. Dengan demikian semua tim kerja adalah kelompok, tetapi hanya kelompok-kelompok formal yang dapat menjadi tim kerja.

Dalam buku "The Essence of Efective Communication" (Komunikasi efektif) karangan Ron Ludlow dan Fergus Panton (1996:110) terjemahan Deddy Jacobus menyatakan pendapat George Homans bahwa : semua kelompok mempunyai tiga unsur yang sama yaitu : (1) aktifitas; (2) perasaan; (3) interaksi"

Selanjutnya Ron Ludlow dan Fergus Panton menjelaskan lebih lanjut bahwa :

1. Aktifitas merupakan apa yang dilakukan orang dalam kelompok untuk memuaskan kebutuhan pribadi, ada untuk mencapai tugas kelompok tersebut, dan ada pula untuk mencapai keharmonisan di dalam kelompok. Aktifitas-aktifitas tersebut mungkin telah dijabarkan terlebih dahulu oleh organisasi atau dikerjakan atas pilihan pribadi.

2. Perasaan : nilai, keyakinan dan sikap yang dibawa para individu kedalam suatu situasi kelompok. Pengaruh sosial kelompok sangat besar terhadap anggota baru, dalam pengertian bahwa para anggota baru dapat mengalami sosialisasi kedalam sikap dan perilaku yang tidak mereka miliki atau tidak diketahui ada sebelum mereka bergabung. Dari sudut pandang organisasi, perilaku yang baru tersebut hendaknya sesuai dengan yang dikehendaki.

3. Interaksi : transaksi antar pribadi terjadi diantara para anggota kelompok. Perilaku yang diperlihatkan hendaknya relevan baik bagi tercapainya tugas, terpeliharanya keharmonisan dan moril kelompok, maupun terpenuhinya kebutuhan pribadi.

Berkaitan dengan hal tersebut di atas, ternyata bahwa kelompok memperlihatkan perilaku yang diinginkan dan perilaku yang "muncul". Perilaku yang diinginkan merupakan perilakù yang dikehendaki organisasi dan dipandang penting untuk kinerja tugas dan keanggotaan organisasi. Hal ini sudah tentu harus dinformasikan kepada para anggota dan bagi mereka yang memenuhi persyaratan akan mendapat imbalan. Perilaku yang diinginkan tersebut dapat berupa perilaku tepat waktu, kerja sama antar anggota tim lain dan pencapaian standar kinerja.

Sedangkan perilaku yang muncul adalah perilaku yang biasa dilakukan anggota baik dalam kaitan prinsip-prinsip organisasi maupun modifikasi dari prinsip-prinsip tersebut. Para individu membuat keputusan pribadi terhadap perilaku yang muncul. 
Keberthasilan kelompok dipengaruhi oleh proses yang digunakan kelompok tersebut dan peran individual para anggota. Efektifitasnya terlihat dari kemampuan masing-masing anggota tim yang memiliki kemampuan khas sebagai berikut:

1. Kemampuan menjelaskan tujuan kelompok'tim dan mengatur aktifitas yaitu menuntun, mengkoordinir dan mengkomunikasikan.

2. Kemampuan mempengaruhi bentuk kelompok menggabungkan, memodifikasi dan membentuk pola tertentu.

3. Kemampuan mencari dan melakukan pendekatan innovatif terhadap masalah

4. Kemampuan menganalisis, terampil, mengasimilasi, mengintęrpretasi dan mengevaluasi data.

5. Kemampuan menata kelompok secara taktis dan praktis sekaligus mengubah ide-ide kedalam bentuk tugas-tugas yang dapat dikelola

6. Kemampuan investigasi yang membantu mempertahankan moril dan antusiasme dan memiliki jaringan kerja yang baik

7. Kemampuan mengelola konfilk dan mengatasi hambatan-hambatan atau masalahmasalah yang timbul.
8. Kemampuan menyelaraskan kepentingan individu dengan kepentingan kelompok

9. Kemampuan bekerja tuntas dengan cara kerja yang teratur, tertib dan terkendali.

Dalam hal ini Isdarmanto, SW, SE juga berpendapat bahwa keuntungan dari pendekatan kemampuan tim : (1) diperoleh input dari berbagai kemampuan dan bukan hanya dari diri sendiri; (2) berkembangnya motivasi pribadi sebagai bagian dari anggota tim; (3) menyumbang suksesnya perusahaan melalui motivasi pribadi untuk peningkatan produktivitas (Isdarmanto, SW; $2003:$ 43)

\section{Pentingnya Tim Dalam Organisasi}

Tim dalam organisasi memiliki bermacam variasi sesuai dengan maksud dan tujuan. Dalam praktik sebuah tim dapat terlibat misalnya dalam pengembangan produk, pemecahan masalah, sebagai bagian dari suatu usaha rekayasa ulang. atau bagi sejumlah kegiatan lain yang berkaitan dengan pekerjaan.

Sebuah tim dapat bersifat tetap atau sementara. Tim-tim departemen fungsional dan tim-tim lain yang merupakan bagian struktur formal organisasi, merupakan jenis tim permanen. Sedangkan tim-tim sementara mencakup satuan tugas, tim proyek, tim pemecahan masalah, tim negosiasi, dan jenis tim lainnya yang merupakan tim jangka pendek yang diciptakan untuk menyusun, meng- 
analisis, mengkaji suatu bisnis atau hal-hal yang berhubungan dengan pekerjaan. Jadi dari pemahaman tersebut di atas tim mempunyai tujuan dilihat dari aspek kategori tim meliputi :

- memngembangkan produk

- pemecahan masalah

- rekayasa ulang

- tujuan organisasi lain yang diinginkan.

Mengenai pentingnya tim dalam organisasi karena tim merupakan kelompok yang dapat dibentuk sesuai maksud dan tujuan organisasi. Tim secara struktur, dapat diawasi dan mengelola diri sendiri. Sedangkan dari aspek keanggotaan bisa fungsional dan lintas fungsional, dan dari aspek jangka waktu bisa permanen dan bersifat sementara.

Beberapa alasan pentingnya tim atau dengan kata lain pentingnya organisasi menggunakan tim :

1. Menciptakan semangat korps, artinya bahwa setiap anggota tim merasa satu bagian dengan bagian lainnya. Hal ini mempermudah kerjasama, memperbaiki semangat kerja karyawan, dan cenderung mendorong para anggota untuk meningkatkan kualitas sekaligus menciptakan iklim yang meningkatkan kepuasan kerja.

2. Mengembangkan kemampuan manajemen untuk berpikir secara strategis. Hal ini di- mungkinkan dengan adanya tim yang mengelola diri sendiri. Jadi dengan menggunakan tim-tim kerja, para manajer dapat menyalurkan kembali energi mereka ke masalah-masalah yang lebih besar misalnya perencanaan jangka panjang.

3. Mampu meningkatkan fleksibilitas dengan menggeser pengambilan keputusan secara vertikal ke bawah timtim, dan memungkinkan organisasi mendapatkan peluang-peluang baru berupa. informasi-informasi yang dapat diakses dari hasil tim-tim kerja tersebut.

4. Menumbuhkan ide-ide yang inovatif dan keputusan-keputusan yang lebih baik dari hasil berbagai latar belakang dan pengalaman tim-tim kerja.

5. Mampu meningkatkan kinerja karena segala unsur atau berbagai faktor bergabung untuk memberi kontribusi bagi organisasi.

\section{Meningkatkan Kinerja dan Menge- lola Tim yang Efektif}

Tim bukan merupakan satusatunya alat pendorong meningkatkan produktivitas organisasi secara otomatis. Bahkan bisa terjadi bila salah kelola maka tim bisa menimbulkan kekecewaan bagi manajemen. 
Oleh karena itu perlu dicermati bagaimana sebaiknya para manajer dapat mengembangkan dan mengelola tim yang efektif dan bagaimana tim dapat dikembangkan ke arah organisasi "jaminan mutu".

Sebuah tim yang efektif adalah tim yang terdiri dari sebuah kelompok , anggotanya terikat dengan suatu maksud bersama, mempunyai serangkaian tujuan-tujuan kinerja yang rinci, dan menganggap mereka itu saling bertanggung jawab bagi hasil-hasil dari timnya. Tim juga dapat menghasilkan ketuaran yang lebih besar dari jumlah kontribusi masing-masing. Kekuatan utama yang membuat sebuah kelompok kerja menjadi tim yang efektif, artinya bahwa sebuah tim memiiki kinerja sangat tinggi dan penekanannya pada kinerja.

Beberapa perilaku yang dapat menciptakan dan mengembangkan tim yang efektif sebagai berikut :

1. Tentukan suatu maksud bersama, sebuah tim yang efektif harus mempunyai maksud bersama yang ingin dicapai oleh semua anggota. Maksud merupakan sebuah visi, hal ini mempunyai makna yang lebih has dari setiap tujuan yang rinci. Maksud bersama ini akan memberikan arah momentum dan niat bagi anggota-anggota tim.

2. Menilai kekuatan dan kelemahan tim. Anggota tim akan mempunyai kekuatankekuatan dan kelemahan-kelemahan yang berbeda-beda. Mengetahui kekuatan dan kelemahan anggota, dapat membantu pemimpin tim membangun dan mengembangkan tim berdasarkan kekuatan tersebut sekaligus mengimbangi kelemahannya.

3. Menyusun tujuan-tujuan individu yang spesifik. Masingmasing tujuan yang spesifik membantu membimbing anggota tim untuk mencapai kinerja yang lebih tinggi. Disamping itu, tujuan yang lebih rinci memperlancar komunikasi yang jelas dan membantu mempertahankan focus agar mencapai hasil yang memuaskan.

4. Mencapai kesepakatan mengenai pendekatan bersama untuk mencapai tujuan. Tujuan adalah hasil akhir yang ingin dicapai oleh tim. Merumuskan dan menyepakati su-atu pendekatan bersama menjamin terintegrasinya sarana-sarana untuk mencapai tujuan-tujuan tadi.

5. Mendorong diterimanya tanggungjawab baik bagi kjnerja masing-masing maupun kinerja kelompok. Tim yang sukses akan membuat anggota-anggotanya secara 
sendiri-sendiri maupun bersama-sama bertanggung jawab atas tujuan tim tersebut, tujuan-tujuannya dan pendekatannya. Para anggota memahami apa yang menjadi tanggung jawab bersama.

6. Membina kepercayaan bersama diantara para anggota. Apabila ada kepercayaan, anggota tim percaya akan kejujuran, watak, dan kemampuan masing-masing anggota. Demikian sebaliknya apabila tidak ada kepercayaan, para anggota tidak mampu saling bergantung. Tim yang tidak memiliki kepercayaan

cenderung akan gagal.

7. Mempertahankan suatu paduan yang tepat dari keterampilan dan kepribadian anggota tim. Anggota tim ada dalam tim tersebut de ngan berbagai macam kepribadian dan keterampilan. Agar tim mampu bekerja efektif, tim membutuhkan tiga jenis keterampilan yaitu individu dengan keterampilan teknis, individu dengan keterampilan menyelesaikan masalah, mengambil keputusan untuk mengidentifikasikan masalah-masalah memunculkan alternatif, mengevaluasi alternatif tersebul, dan menetapkan pilihan yang bijaksana. Berikutnya tim membutuhkan anggota dengan keterampilan negosiasi dan berkolaborasi serta berpikir taktis.

8. Memberikan pelatihan dan ketersediaan sumber daya yang dibutuhkan tim untuk mencapai tujuan-tujuannya.

9. Menciptakan peluang bagi anggota tim dan mendorong untuk mencapai prestasi kecil pada awalnya. Karena membangun tim yang efektif membutuhkan waktu. Anggota tim harus terus belajar untuk berpikir fan bekerja sebagai tim. Tim yang bekerja tidak langsung dapat diharapkan sukses setiap bekerja.

10.Adanya dukungan internak dan eksternal, iklim yang kondusif dan infrastruktur yang sehat dapat menopang para anggota serta memperkuat perilaku yang menjurus pada tingkat kinerja yang tinggi.

Berkaitan dengan mengembangkan tim yang efektif penulis mengadaptasi pendapat Bartolome dalam tulisannya di Harvard Business Review dengan judul * Nobody Trusts The Boss Completely- Now What ?" yang terjemahannya sebagai berikut :

“1. Komunikasi. Jagalah anggota tim dan bawahan men- 
dapat informasi dengan menyelaraskan keputusan dan kebijakan dan berikan umpan balik yang tepat. Jujurlah dengan masalah dan keterbatasan manajer.

2. Bersikaplah mendukung. Bersikaplah untuk dapat ditemui dan didekati. Doronglah dan dukung gagasan-gagasan anggota tim.

4. Berșikaplah hormat. Delegasikan wewenang yang nyata kepada anggota tim dan dengarkan gagasan mereka.

5. Bersikaplah agar mudah ditebäk. Bersikap konsisten dalam urusan sehari-hari. Penuhilah janji secara eksplisit sebagaj pimpinan maupun implicit yang telah diucapkan.

6. Perlihatkan kompetensi. Kembangkan kekaguman dan rasa hormat dari para anggota tim dengan memperlihatkan kemampuan teknis, professional, dan kepekaan terhadap peluang bisnis yang baik. "(1989: 135)

Keenam butir tersebut di atas merupakan saran untuk membantu manajer sebagai pemimpin dalam membangun kepercayaan guna mengembangkan tim secara efektif. Pendapat Bartolome tersebut di atas lebih menekankan, membangun kepercayaan.
Di samping mengembangkan tim secara efektif, implementasi berikutnya bagaimana mengelola tim. Tugas mengelola sebuah tim dengan melakukan pendekatan menggunakan keempat fungsi dasar manajemen meliputi : perencanaan, pengorganisasian, pemimpinan dan pengendalian.

to Perencanaan. Penentuan sasaran merupakan bagian penting proses perencanaan. Hal ini penting karena tim yang efektif harus me. miliki tujuan yagn jelas. Para anggota tim sudah seharusnya mema. hami dan menerima tujuan tim tersebut. Apakah sasaran-sasaran untuk tim tersebut misalnya dalam hal tim rekayasa ulang diberi tugas untuk mendesain ulang proses-proses kerja, atau tim tersebut mengembangkannya tujuan-tujuannya sendiri, setiap anggota harus memahami apa tujuan tersebut. Salah satu cara praktis untuk mengetahui pemahaman-pemahaman anggota tentang tujuan-tujuan tersebut dengan meminta masing-masing anggota tim menuliskan sasaran-sasarn timnya, kemudian mengumpulkan dan menganalisis pernyatàan-pernyataan anggota untuk mengetahui ketepatan dan konsistensi. Apabila terdapat kesalahpahaman ataupun salah persepsi mengenai sasaran-sasaran tim, maka pertemuan dapat diadakan untuk menjelaskan hal-hal tersebut. 
Pengorganisasian. Pengorganisasian tugas-tugas yang mencakup mengelola sebuah tim termasuk menjelaskan wewenang dan masalah-masalah struktural. Salah satu pertanyaan kunci bagi sebuah tim adalah seberapa banyak wewenang yang mereka miliki. Apabila tim tersebut mengarahkan diri sendiri atau mengelola diri sendiri, maka tim tersebut telah diberdayakan dengan wewenang untuk membuat keputusan-keputusan tertentu dan mengerjakan kegiatan-kegiatan tertentu. Walaupun demikian sekalipun tim tersebut bukan suatu tim yang mengelola diri sendiri, maka yang perlu mendapat perhatian mengenai apa yang boleh dan tidak boleh dilakukan oleh tim tersebut. Jika budaya organisasi mendukung otonomi dan keterlibatan karyawan, maka kemungkinan besar bahwa tim-tịn kerja akan memiliki lebih banyak wewenang atas apa yang mereka kerjakan dan bagaimana mereka melakukannya. Akan tetapi yang penting adalah bahwa masalah-masalah wewenang ini hendaknya ditangani sejak awal agar sebuah tim mengetahui parameter dan kendala-kendalanya. Dan di dalam tim itu sendiri, masalahmasalah struktural perlu ditegaskan. Apakah sudah ditunjuk seorang pemimpin dan apakah tim tersebut yang akan menunjuk menunjuk seorang pemimpin ? tugas-tugas apa yang harus dilakukan untuk mencapai tujuan-tujuan tim itu ? apa cara yang paling efektif dan efisien untuk melakukan pekerjaan itu ? siapa saja yang akan diberi berbagai macam tugas itu dan bagaimana penunjukan-penunjukan tersebut akan dibuat ? ini merupakan jenis-jenis pertanyaan struktural yang perlu dijawab oleh tim.

Kepemimpinan. Masalah-masalah penting dalam pemimpinan yang harus ditangani oleh sebuah tim meliputi antara lain, peran apa yang akan dilakukan atau dimainkan sipemimpin, bagaimana konflik akan ditangani, dan proses komunikasi akan digunakan. Pemimpin tim tersebut memainkan peranan penting dalam mengarahkan usaha-usaha tim tersebut. Dan perlu diketahui bahwa tim-tim yang efektif, dalam arti pemimpin-pemimpin tim makin lama tidak lebih menjadi seorang fasilitator dan orang yang terlatih, dan bukan orang yang berkuasa. Memimpin tim menuntut orang untuk memiliki pengetahuan teknis yang cukup agar sipemimpin dapat memahami tugas-tugas tim tersebut dan memiliki keterampilan-keterampilan hubungan antar pribadi yang kuat sehingga pemimpin tersebut dapat memudahkan keikutsertaan anggota masing-masing, mendorong kinerja yang luar biasa, menyelesaikan konflik-konflik dan mendapatkan kesepakatan mengenai masalah-masalah penting. Menghadapi dinamika manusiawi tim tersebut, seringkali 
merupakan bagian-bagian paling sulit dalam mengelola sebuah tim.

Pengendalian. Fungsi ini tinjauannya dalam kaitan dengan mengelola tim adalah fungsi. pengendalian. Ada dua hal dalam masalah pengendalian yaitu : Bagaimanakah kinerja tim tersebut akan dievaluasi den jenis sistem imbalan apakah yang akan digunakan ? sewaktu organisasi-organisasi mulai lebh banyak menggunakan tim, sistem penilaian karyawan dan sistem imbalan mereka harus diubah untuk mencerminkan hal tersebut. Jenis-jenis perubahan macam apakah yang boleh kita harapkan ?

Sehubungan dengan hal tersebut di atas maka kriteria kinerja hendaknya dimodifikasikan guna menggabungkan perilaku-perilaku kerja tim dalam penilaian karyawan. Menurut Stewart seperti terjemahan di bawah ini menyatakan:

"Bukan saja kinerja individu yang harus dievaluasi, melainkan juga faktor yang menunjukkan seberapa baik individu tersebut bekerja, dalam konteks timnyapun harus dipertimbangkan pula, misalnya pada Ideo, sebuah perusahaar desain Industri, penilaian kinerja sekarang mencakup komentar-komentar dari sesama tim maupun dari para manajer" (Stewart, TA, 1996 : 165)

Akan tetapi perubahan-perubahan dalam proses penilaian untuk memasukan usaha-usaha tim ternyata tidak berjalan sepenuhnya.
Oleh karena itu perlu diperhatikan sejauh mana tim-tim tersebut mendapat imbalan atas usaha-usaha dan tingkat kinerja mereka. Sewaktu organisasi semakin sering menggunakan tim-tim tersebut, mulai terlihat meningkatnya penggunaan rancangan insentif kelompok. Salah satu pendekatan paling sering digunakan terhadap insentif kelompok adalah pendekatan keuntungan bersama. Pendekatan keuntungan bersama merupakan suatu program insentif yang membagikan keuntungan langsung berkaitan dengan kinerja. Apabila tim tersebut berhasil, maka anggota-anggota tim akan mendapat imbalan. Organisasi yang didasarkan pada tim menggunakan pula imbalan-imbalan seperti bonus satu kali, insentif tim, program-program kredit point yang didasarkan pada kinerja karyawan dan penghargaan pada tim informal. Akan tetapi apapun pendekatan yang digunakan, tim tersebut haruslah merupakan kekuatan utama dalam menentukan jenisjenis imbalan dan pengakuan apa yang penting.

\section{Penutup}

Menutup alienasi akhir dari tulisan ini ada beberapa kesimpulan yang dapat dicermati sebagai berikut:

1. Bahwa orang atau incividu bergabung dengan kelompok-kelompok karena kebutuhan mereka akan rasa 
aman, status, harga diri, afiliasi, kekuasaan dan atau prestasi.

2. Dalam kajian-kajian ada beberapa tahap pertumbuhan kelompok yaitu tahap yang mencakup orang yang bergabung dengan kelompok kemudian merumuskan tujuan, struktur dan kepemimpinan kelompok tersebut. Tahap berikutnya merupakan tahap konflik di dalam kelompok tersebut mengenai masalah pengendalian, kemudian dari tahap tersebut tumbuh ikatan-ikatan erat dan kelompok tersebut menunjukan keterpaduan. Selanjutnya tahap implementasi kelompok tersebut menyelesaikan tugas yang dihadapi. Pada tahap akhir adalah tahap pada saat komite, satuan tugas, dan tim tugas temporer melakukan tugas terbatas.

3. Bahwa ada suatu peran merunjuk pada serangkaian pola perilaku yang diharapkan dari seseorang menempati posisi tertentu dalam sebuah unit. Pada waktu tertentu pula, para karyawan menyesuaikan perilaku peran mereka dalam kelompok tempat mereka menjadi bagiannya. Norma merupakan patokanpatokan yang dimiliki ber- sama oleh kelompok. Norma-norma tersebut secara informal dipahami oleh para karyawan perilaku mana yang dapat diterima dan mana yang tidak dapat diterima.

4. Keunggulan pengambilan keputusan kelompok adalah : informasi yang lengkap, lebih banyak alternatif, lebih diterimanya suatu pemecahan, dan semakin besar legitimasinya.

5. Tim semakin banyak digunakan oleh organisasi karena tim membina semangat ko. rps, membebaskan manajemen untuk lebih banyak melakukan pemikiran strategis, memungkinkan pengambilan keputusan lebih cepat, mempermudah keragaman angkatan kerja, pada akhirnya meningkatkan kinerja.

6. tim kerja yang eféktif dicirikan oleh tujuan yang jelas, anggota dengan keterampilan yang sesuai, kepercayaan timbal balik di antara para anggota, komitmen terpadu, komunikasi yang baik, keterampilan-keterampilan negosiasi dan kolaborasi serta kepemimpinan yang tepat.

7. Para manajer dapat membina kepercayaan dengan berkomunikasi secara terbuka, memberikan dukungan ter- 
hadap ide-ide para anggota tim, bersikap hormat-adil dan dapat diramalkan, dan menunjukan kompetensi masing-masing para anggota tim.

8. Tim pemecahan masalah tumbuh dengan sendirinya dan merupakan wahana alami bagi para karyawan untuk menyampaikan ide-ide dan melakukan perbaikan-perbaikan sebagai bagian dari proses jaminan mutu dan efektif untuk memecahkan masalah-masalah yang kompleks.

\section{Daftar Pustaka}

Bartolome, F. 1989. Nobody Trusts the Boss Completely Now What ?. Harvard Business Review (March-April)

Didi Wahyu Sudirman, MM., 2002.

Tim Building (Materi Pelatihan), Yogyakarta PT Gama Spektra Mandiri
Isdarmanto, S.E., S.E.,2003. Communications, Assertiveness and Confict Management, Yogyakarta, PT Wish Consultant \& Training Specialist.

Ludlow, Ron dan Fergus Panton, 1996. The Essence of Effective Communication

(Komunikasi Efektif). Terj. Deddy. Jalobus, Yogyakarta, Penerbit Andi.

Stewart, T.A, 1996, The Great Conundrum-You Vs The Team. Fortune (November)

Biodata Penulis

Didi Wahyu Sudirman, MM adalah salah satu staf pengajar pada Program Studi Pendidikan Administrasi Perkantoran FIS-UNY 